\title{
Characterization and Classification of different Soil Type of Gariyaband District of Chhattisgarh
}

\author{
Deepika Devdas*, L. K. Srivastava and V. N. Mishra \\ Department of Soil Science and Agricultural Chemistry, IGKV, Raipur (C. G.), India \\ *Corresponding author
}

\section{A B S T R A C T}

Keywords

Characterization, Classification, Soil

Profile study, Soil type

\section{Article Info}

\section{Accepted:}

15 January 2021

Available Online:

10 February 2021
A study was carried out during 2014-15 on soil characterization and classification of Gariyaband district of Chhattisgarh. The objectives of the study were to characterize the major soil types of the district. Three soil profiles were identified, excavated, described and sampled for morphological, physical and chemical properties and were classified in to three different soil- groups. Pedon-1 indicated the presence of cambic B horizons and placed in Inceptisols, pedon-2 showed argillic horizons keyed out in Alfisols and pedon-3 was classed in Vertisols soil order due to the presence of wide cracks, slicken sides and high clay content. All the pedons belonged to Usteps suborder since they had Ustic soil moisture regime. The horizons were simple and no calcic orgypsic or duripan were observed, they were placed in Haplustepts Great Group. All the pedons represented the central concepts of great group and hence classified as Typic Haplusteps at subgroup level. Based on the different properties the soils were classified as for pedon -1 as Fine sand clay loamy, kaolinitic hyperthermic, Typic Haplustepts, pedon-2 as Fine clay loamy, kaolinitic mixed hyperthermic, Typic Haplustalfs and pedon-3 as Fine clay, Montmorillonitic mixed hyperthermic, Typic Haplusterts.

\section{Introduction}

Soil is the uppermost layer of variable depth of the earth consisting of loose material, which is the main support for natural vegetation and other life forms of our planet. Soil is an independent dynamic body of nature that acquires properties in accordance with the forces which act upon it. The important soil forming factors such as parent material, climate, relief, organism and time have direct impact on soil properties. The soil forming processes as oxidation, reduction, eluviations and illuviation are related to soil solution and further on stages of soil development (Tamgadge et al., 2002). Soil profile characteristics as conditioned by different processes and factors of soil formation have great influence on fertility of soil and productivity of land. Therefore an 
understanding of morphology and physicochemical characteristics in relation to added fertilizer is necessary to suggest appropriate fertilizer schedule for different crops in order to obtain optimum yield (Mishra, 2005). Knowledge of vertical distribution of plant nutrients in soil is useful as roots of most of the crop plants go beyond the surface layer and draw part of their nutrient requirements from the sub-surface layer (Brar and Sekhon, 1987; Pal and Muckhopadhyay, 1992; Sangwan and Singh, 1993; Kumar et al., 1996). Soil characterization and classification provides an accurate and scientific inventory of different soils, their kind and nature, and extent of distribution so that one can make prediction about their characters and potentialities. It also provides adequate information in terms of land form, slope, profile characteristics of soils (viz., depth, color, texture, structure etc.) which can be utilized for the planning and development.

\section{Materials and Methods}

Chhattisgarh state has been divided into three agro-climatic zones viz. Chhattisgarh plains, Bastar Plateau, and Northern hills zone covering 51, 28 and $21 \%$ of the geographical area, respectively. The location of the state is such that it is close to the Bay of Bengal, which is instrumental in bringing monsoon in the Northern part of the country. The state lies at $17^{\circ} 46^{\prime} \mathrm{N}$ to $24^{\circ} 5^{\prime} \mathrm{N}$ latitude and $80^{\circ} 15^{\prime} \mathrm{E}$ to $84^{\circ} 20^{\prime} \mathrm{E}$ longitude.

Gariyaband district is situated in the fertile plains of Chhattisgarh Region. This district is situated between $20^{\circ} 57^{\prime} \mathrm{N}$ and $81^{\circ} 53^{\prime} \mathrm{E}$ and at an altitude of 292 meters MSL. The Gariyaband district is surrounded by district Raipur, Mahasamund, Dhamtari and Orissa State in the East. The present investigation were carried in 91 villages out of 710 villages of five blocks (viz., Fingeshwar, Chhura, Gariyaband, Mainpur and Devbhog) in
Gariyaband district of Chhattisgarh. Geographical and other information related to district given in Table 1 . The region comes under hot, sub humid climate, having average rainfall of $1157.1 \mathrm{~mm}$. The maximum temperature during the summer may exceed up to $46^{\circ} \mathrm{C}$ and the minimum temperature often falls below $9.0^{\circ} \mathrm{C}$ during winter season. The hottest and coolest months are May and December, respectively.

Geological and morphological parameters were used to facilitate the selection. Three soil profiles were identified, excavated, described and sampled following standard procedures (FAO, 1977; Munsell Color Company, 1954; Soil Survey Staff, 1999). The colour of the soil horizons were determined by matching the colour with Munshell Soil Color Chart. Exact locations of the sites in terms of international coordinates were determined using Global Positioning System (GPS) Receiver.

\section{Results and Discussion}

\section{Morphological Characteristics of Soils}

Three representative pedons were examined for morphological properties and results are presented in Table 2.

\section{Depth of soil}

The results presented in Table 2 revealed that the depth of different pedons varied from 70 $\mathrm{cm}$ to $156 \mathrm{~cm}$. The lowest depth of $70 \mathrm{~cm}$ was observed in pedon-1 and depth of pedon- 2 and pedon-3 were recorded 155 and $156 \mathrm{~cm}$, respectively. The soils on more slopping positions are generally shallow and have weekly-developed profile in pedon-1due to accelerated erosion that removes surface materials before it has time to develop. Percolation of water through the soil gets reduced because of runoff. Moreover, availability of water to plants is reduced which 
are responsible for checking of erosion and soil formation. On nearly leveled topographic positions, almost the entire water received as rainfall percolate through the soil. Therefore, deep profiles were observed in pedon- 2 and pedon-3. Similar result was also observed by Parmasivan and Jawahar (2014) and they reported that the maximum depth of the soils Vertisols ranged from 115 to $150 \mathrm{~cm}$ in southern region of Tamil Nadu state of India.

\section{Soil Color}

The data in Table 2 presents morphological characteristics of three representative pedons of the Gariyaband district. It is evident from the results that yellowish brown (10YR5/4) to very dark gray $(10 \mathrm{Y} 3 / 1)$ in color. The yellowish brown (10YR 5/4 to 10YR 5/6) color in case of pedon-1, dark grayish brown $(2.5 \mathrm{Y} 3 / 2)$ to grayish brown $(2.5 \mathrm{Y} 5 / 2)$ color for pedon-2 and gray (10YR5/1) to very dark gray (10YR3/1) for pedon-3 were observed. Meena et al., (2014) and Bhaskar and Sarkar (2013) observed the similar characteristics for Inceptisols of Hubali district at Karnataka. In case of pedon-3, lower chromas exhibited darker color in surface horizon due to presence of higher organic matter contents. However, at lower depth higher chromas with decreasing level of organic matter were also recorded. Such reports were also presented by Parmasivan and Jawahar (2014) who had noticed hue 10 YR with value varied from 3-4 and chroma 1-2 due to the occurrence of free cations in Vertisols of southern region at Tamil Nadu.

\section{Soil Texture}

The data presented in the Table 2 indicate that textural classes of soil of different pedons varied from sandy clay loam to clay soil. Sandy clay loam texture was observed in surface and subsurface horizons of pedon-1. Likewise, Meena et al., (2014) reported that the sandy loam to sandy clay loam texture were observed in surface and subsurface soils (Inceptisols) of Hobli district of Karnataka. Pedon-2 displayed clay loam texture in surface and subsurface horizons up to depth $77 \mathrm{~cm}$ and sandy clay texture were found in other lower horizons of pedon-2. Clayey texture was found in entire horizons of pedon-3 and clay content progressively increased in lower horizons. These results are in accordance with the earlier findings of Srinivasa Rao et al., (2008) in Black soils where clay content increased with increase in depth. The mean values of sand percent were 58.17, 39.18 and 28.3 in pedon-1, pedon-2 and pedon-3 respectively. Sand fraction decreased with increasing soil depth in pedon-1 however, pedon- 2 and pedon-3 showed an increasing trends. The average percent of silt fraction in three pedons (pedon-1, pedon-2 and pedon-3) were in the order of $11.93,23.20$ and 17.88, respectively. In general, these fractions was found higher in surface horizons and lower percent were found in sub surface horizons of pedons-2 and pedon-3, while such variation was not observed in pedon-1 although it decreased in lower horizon. The average values of percent clay contents were 29.90, 37.62 and 53.82 in pedon-1, pedon- 2 and pedon-3, respectively. The percent clay content was lower in upper horizons and increased with increasing depth. The enrichment of clay content in lower horizon may be due to illuviation or vertical migration of clay. Similar results were also opined by Sarkar et al., (2002).

\section{Soil Structure}

The data pertaining to soil structure in three pedons are presented in Table 2. Results revealed that subangular blocky (sbk) type of structure was identified in all pedons except inpedon-2 wherein angular blocky type structure was observed in subsurface horizon $\left(\mathrm{B}_{\mathrm{t} 4}\right)$. Week grade (1) in surface horizon of the 
pedon- 1 and pedon-3 and moderate grade (2) was found in pedon-2. Subsurface horizon $(2, \mathrm{~m}, \mathrm{sbk})$ were noticed to be common in pedon- 1 and pedon- 2 .

Subsurface horizon $(3, \mathrm{~m}, \mathrm{sbk})$ were found in pedon-2, Almost all the horizons of the profiles strong, medium, and sub angular blocky $(2, \mathrm{~m}, \mathrm{sbk})$ and angular blocky $(3, \mathrm{~m}, \mathrm{abk})$ type of structure observed in subsurface horizon which may be attributed to higher clay content and low organic matter content (Singh and Agrawal, 2005).

The surface horizon of pedon-1 had very hard (dry) and friable (moist) consistency. Whereas, Pedon-3 showed characteristics of Vertisols such as slickensides, pressure faces and cracks. These soils had well developed slickenside in Bss3.

Intersecting slickensides forming structural aggregates that break mostly to strong coarse, angular blocky peds. Few, very fine to fine roots 2 to $11 \mathrm{~cm}$ wide with continuous vertical cracks and diffused wavy boundaries between horizons has been observed. Similar characteristics of Vertisols group was also described by Ram et a.,l (2010).

\section{Bulk Density}

Bulk density of different horizons Table 2 ranged from 1.36-1.47, 1.32-1.49 and 1.24 $1.37 \mathrm{Mg} \mathrm{m}^{-3}$ with mean value of $1.43,1.41$, and $1.31 \mathrm{Mg} \mathrm{m}^{-3}$ in pedon -1 ,pedon -2 and pedon -3 , respectively. In general, bulk density increased with depth. Lower bulk density of surface soils could be attributed to higher organic matter content (Rao et al., 2008), whereas higher bulk density in subsurface horizons might be due to greater compaction in soils (Jewitt et al., 1979; Ahuja et al., 1988).

\section{Soil reaction (pH) and electrical conductivity}

The data in Table 3 showed the $\mathrm{pH}$ values of different pedons. The $\mathrm{pH}$ value ranged from 5.7 to $6.1,6.1$ to 7.3 and 7.0 to 7.9 with an average value of 5.3, 6.6 and 7.4 of pedon-1, pedon-2 and pedon-3, respectively. The $\mathrm{pH}$ value was lower in surface soil and increased in sub surface horizons of all pedons.

The variations in $\mathrm{pH}$ with varying soil depth may be ascribed due to intensive weathering and subsequent leaching of bases in sloping landforms as reported by (Patagundi et al., 1996; Nayak et al., 2002). Baruah et al., (2014) also reported similar results in Alfisols in Gerua farm of Assam state.

These soils are slightly acidic to mildly alkaline ( $\mathrm{pH}$ of 6.1 to 7.6). In Vertisols, the soil reaction ranged from moderately alkaline $(\mathrm{pH}$ 7.9 to 8.6 ) in surface and sub surface horizons. These results are in line with the findings of Parmasivan and Jawahar (2014).

Electrical conductivity in three pedons recorded in the range of 0.02 to $0.03,0.02$ to 0.29 and 0.54 to $0.99 \mathrm{dS} \mathrm{m}^{-1}$ with mean value of $0.03,0.09$ and 0.07 for pedon -1 , pedon -2 and pedon -3 , respectively. Our results corroborated the reports of Raam et al., (2014). The concentrations of soluble salts varied in different pedons however, values fall under the normal range (Table 3). Almost similar salt concentration was found in surface and sub surface horizons of all pedons except $\mathrm{B}_{\mathrm{ss} 3}$ horizon (depth 110-156 cm) of pedon-3.

Salts in different horizons increased with depth in all the horizons which might be due to translocation of salts from upper layers and their accumulation in lower horizon (Graget al., 2000). 
Table.1 Salient features of profile under investigation

\begin{tabular}{|c|c|c|c|}
\hline & Pedon-1 & Pedon-2 & Pedon-3 \\
\hline Location & $\begin{array}{l}\text { Village -Mohanda } \\
\text { Tehsil- Mohanda } \\
\text { Distt- Gariyaband }\end{array}$ & $\begin{array}{c}\text { KVK farm - Gariyaband } \\
\text { Tehsil- Gariyaband } \\
\text { Distt- Gariyaband }\end{array}$ & $\begin{array}{c}\text { Village - Kokdi } \\
\text { Tehsil- } \\
\text { Gariyabandh } \\
\text { Distt- } \\
\text { Gariyabandh }\end{array}$ \\
\hline $\begin{array}{l}\text { Physiographic } \\
\text { position }\end{array}$ & $\begin{array}{l}20^{0} 22^{\prime} \mathrm{N} \text { latitude } \\
83^{0} 13^{\prime} \text { E longitude }\end{array}$ & $\begin{array}{c}20^{0} 38^{\prime} \text { N latitude } \\
82^{0} 04^{\prime} \text { E longitude }\end{array}$ & $\begin{array}{l}20^{0} 38^{\prime} \text { ' latitude } \\
82^{0} 57^{\prime} \text { E longitude }\end{array}$ \\
\hline $\begin{array}{l}\text { Annual av. } \\
\text { rainfall ( } \mathbf{m m})\end{array}$ & $1200-1400 \mathrm{~mm}$ & $1200-1400 \mathrm{~mm}$ & $1200-1400 \mathrm{~mm}$ \\
\hline Land slope & $\begin{array}{c}3-6 \% \\
\text { Gently slopping }\end{array}$ & $\begin{array}{c}1-4 \% \\
\text { Very gently slopping }\end{array}$ & $\begin{array}{c}1-3 \% \\
\text { Very gently } \\
\text { slopping }\end{array}$ \\
\hline $\begin{array}{l}\text { Drainage and } \\
\text { permeability }\end{array}$ & $\begin{array}{l}\text { Well drain and slow } \\
\text { permeability }\end{array}$ & $\begin{array}{l}\text { Moderately drain and } \\
\text { slow permeability }\end{array}$ & Poorly drain \\
\hline $\begin{array}{l}\text { Land use and } \\
\text { vegetation }\end{array}$ & $\begin{array}{l}\text { Urd, } \\
\text { Tamarin } \\
\text { d, Babul, Plum }\end{array}$ & $\begin{array}{l}\text { Chickpea Paddy, Wheat, } \\
\text { Tamarind, Guava, Plum }\end{array}$ & $\begin{array}{c}\text { Paddy, palaas and } \\
\text { Babul, }\end{array}$ \\
\hline $\begin{array}{c}\text { Geology and } \\
\text { parent material }\end{array}$ & $\begin{array}{l}\text { Quartzide, } \\
\text { sandstone }\end{array}$ & Alluvium & Alluvium \\
\hline
\end{tabular}

Plate.1 Soil belonging to Inceptisols

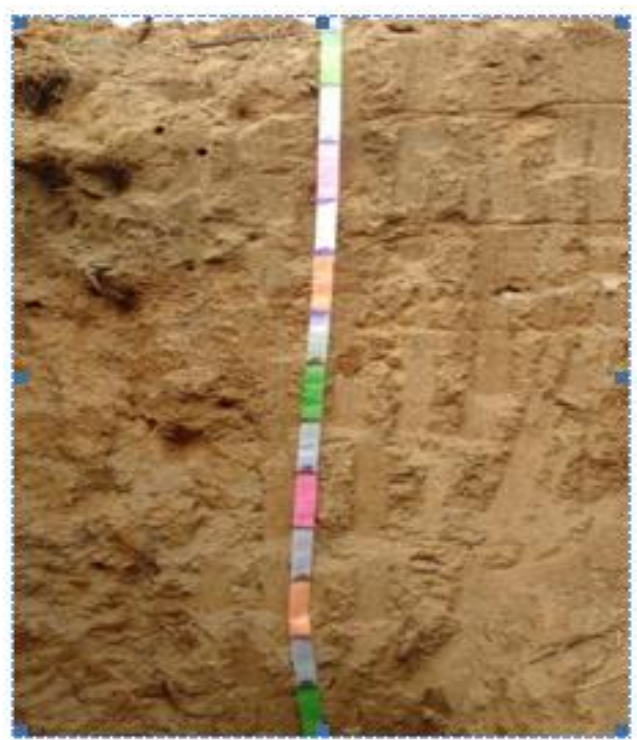

Plate.2 Soils belonging to Alfisols

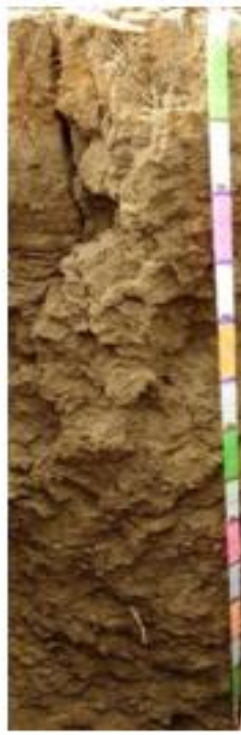

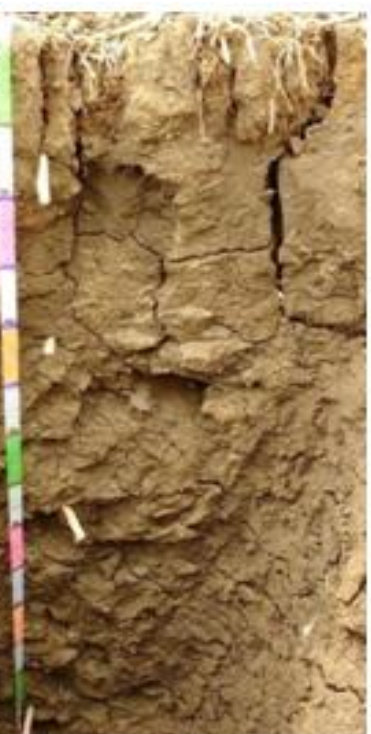

Plate.3 Soil belonging to Vertisols

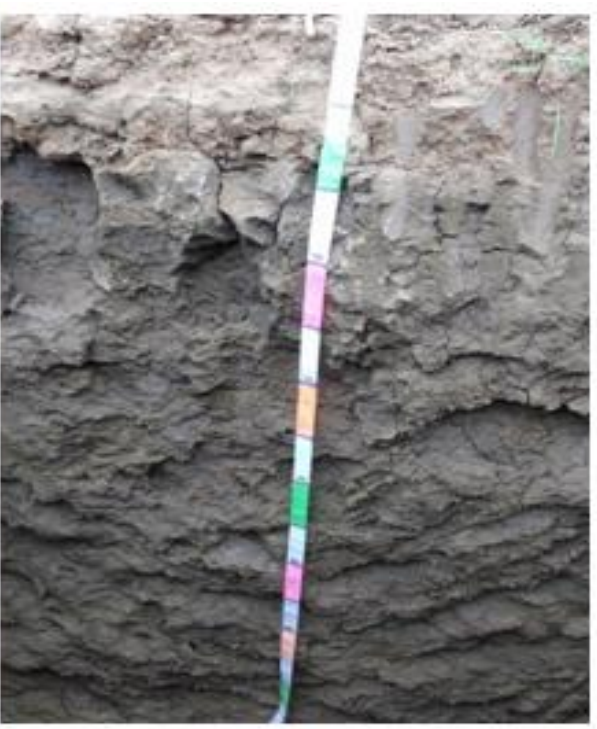


Table.2 Morphological and physical properties of the Pedons

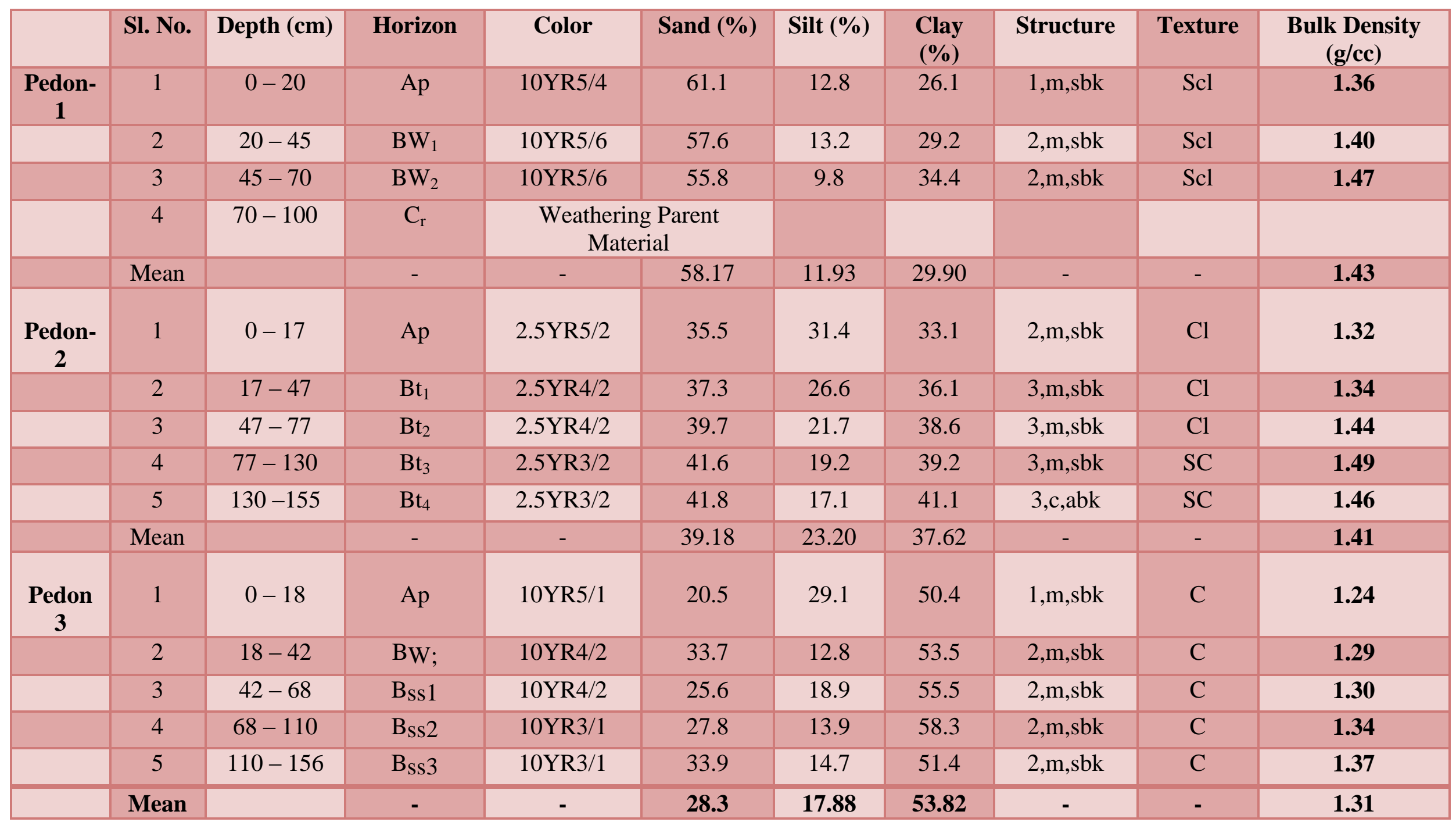


Table.3 Chemical properties of the Pedons




Table.4 Classification of the different soils identified in Gariyaband district

\begin{tabular}{|c|c|c|}
\hline Pedons & Classification & Soil order \\
\hline Pedon 1 & Fine sand clay loamy, kaolinitichyperthermic, Typic Haplustepts & Inceptisols \\
\hline Pedon 2 & Fine clay loamy, kaolinitic mixed hyperthermic,Typic Haplustalfs & Alfisols \\
\hline Pedon 3 & $\begin{array}{c}\text { Fine clay, Montmorillonitic mixed } \\
\text { hyperthermic,TypicHaplusterts }\end{array}$ & Vertisols \\
\hline
\end{tabular}

\section{Cation exchange capacity}

Cation Exchange Capacity (CEC) of the soil from three pedonsunder study as shown in Table 3 revealed that CEC of the surface soils varied from 13.71 to $17.83,20.60$ to 37.60 and 33.70 to $49.10 \mathrm{meq}+/ 100 \mathrm{~g}$ with mean value of $15.53,29.82$ and $42.98 \mathrm{meq}+/ 100$ gfor pedon 1 , pedon -2 and pedon -3 , respectively. The CEC of pedons were related to the content of cations on exchange complex. Since the soils with high $\mathrm{pH}$ value contain more exchangeable bases, they have high CEC. High CEC with increase in depth in different horizons may be attributed to the higher clay content in the lower layers. Similar results were also reported by Chaudhary et al., (2006), Baruah et al., (2014) and Parmasivan and Jawahar (2014).

\section{Organic Carbon}

The organic carbon content is an indicator of available nitrogen status of soils. Organic carbon content in soils of three pedons (pedon-1, pedon-2 and pedon-3) ranged from 0.33 to $0.56,0.27$ to 0.73 and 0.31 to 0.70 per cent with their mean value of $0.42,0.51$, and 0.51 per cent, respectively (Table 3 ). Organic $\mathrm{C}$ contents were found higher in surface soil than those of lower horizons. Decreasing trends in organic carbon content with lower soil depth/horizons in all three pedons might be due to the fact that less crop residues than surface layer. Similar results were also reported by Raam et al., (2014) in Inceptisols, Baruah et al., (2014) in Alfisols and Parmasivan and Jawahar (2014) in Vertisols.

\section{Available N, P and K}

The available $\mathrm{N}, \mathrm{P}$, and $\mathrm{K}$ contents in three representative pedons are given in Table 3. It is obvious from the data that available nitrogen contents ranged from 213 to 125 with their mean value of $158 \mathrm{~kg} \mathrm{ha-}{ }^{1}$ in pedon- 1 , 112 to 376 with mean value of $194 \mathrm{~kg} \mathrm{ha-}{ }^{1}$ in pedon- 2 and 88 to $401 \mathrm{~kg} \mathrm{ha}^{-1}$ with mean value of $249 \mathrm{~kg} \mathrm{ha}^{-1}$ in pedon-3.

The available phosphorus contents ranged from 7.90 to 14.50 with mean of $11.80 \mathrm{~kg}$ $\mathrm{ha}^{-1}, 10.08$ to 22.43 with mean of 15.31 and 10.6 to 38.10 with mean of $18.90 \mathrm{~kg} \mathrm{ha}^{-1}$, for pedon-1, pedon-2 and pedon-3, respectively.

The available potassium ranged from 136 to 163 with mean of $153 \mathrm{~kg} \mathrm{ha}^{-1}, 166$ to 490 with mean of $273 \mathrm{~kg} \mathrm{ha}^{-1}$ and 416 to 511 with mean value of $451 \mathrm{~kg} \mathrm{ha}^{-1}$ for pedon-1, pedon-2 and pedon-3, respectively.

The low nitrogen, phosphorus and potassium content in Inceptisols could be attributed due to their low organic carbon contents (Prasuna Rani et al., 1992), fixation of released phosphorus by clay minerals and oxides of $\mathrm{Fe}$ and Al (Vijay Kumar et al., 1994).

In Alfisols and Vertisols, medium to high content of potassium may be due to weathering of $\mathrm{K}$ bearing minerals and release of $\mathrm{K}$ from organic residues (Sharma and Anil Kumar 2003 and Rao et al., 2008). Similar results were also reported by Raam et al., (2014) and Parmasivan and Jawahar (2014). 


\section{Available S}

Available sulphur contents shown in Table 3 varied from 13.90-39.33, 12.52-46.50 and $38.90-66.90 \mathrm{~kg} \mathrm{ha}^{-1}$ in the surface and sub surface soils with an average value of 24.81, 28.06 and $49.14 \mathrm{~kg} \mathrm{ha}^{-1}$ in pedon-1, pedon-2 and pedon-3, respectively.

The available sulphur showed decreasing trend with depth in all three pedons. The range and trend of available sulphur was matched with results found in Inceptisols and Vertisols of Prakasm district of Andhra Pradesh as reported by Raam et al., (2010).

\section{Available B}

Available B contents (Table 3 ) in three pedons varied from 0.25 to $0.69,0.24$ to 0.72 and 0.48 to $0.78 \mathrm{mg} \mathrm{kg}^{-1}$ in the surface and subsurface depth with an average value of $0.46,0.51$ and $0.60 \mathrm{mg} \mathrm{kg}^{-1}$ in pedon -1 , pedon-2 and pedon3 , respectively. Available $\mathrm{B}$ statuses were higher in top soils and decreased with lower depth in all pedons. Raamet al., (2010) observed the available $\mathrm{B}$ content in the range of 0.12 to $0.72 \mathrm{mg} \mathrm{kg}^{-1}$ with an average value of $0.42 \mathrm{mg} \mathrm{kg}^{-1}$. The concentrations of hot water soluble B ranged from 0.38 to $0.84 \mathrm{ppm}$ in salt affected soils of Punjab (Sharma and Bajwa 1989), whereas in alluvium derived soils from Ferozepur and Faridkot districts of Punjab, it ranged from 0.20 to $3.85 \mathrm{mg} \mathrm{kg}^{-1}$ soil (Singh and Nayyar 1999).

\section{Available micronutrients}

Available $\mathrm{Cu}$ content DTPA-extractable (Table 3 ) in three pedons varied from 0.30 to 1.10 , 0.20 to 0.80 and 0.40 to $1.20 \mathrm{mg} \mathrm{kg}^{-1}$ in the surface and subsurface depth with an average value of $0.29,1.08$ and $0.98 \mathrm{mg} \mathrm{kg}^{-1}$ in pedon 1 , pedon-2 and pedon-3, respectively.

Available Fe varied from 20.6 to $44.2,8.6$ to 34.3 and 10.1 to 26.6 with mean $29.63,23.80$ and 19.78, available $\mathrm{Mn}$ content varied from 16.80 to 26,24 to 45 and 18.6 to 31.8 with average 21.13, 33.98 and 24.40. Available $\mathrm{Zn}$ ranges from $0.4-1.1,0.6-1.1$ and $0.6-0.8$ with average $0.77,0.72$ and 0.68 . These results are supported by Katyal and Rattan (2003) and Parmasivan and Jawahar (2014) in southern Tamil Nadu.

\section{Soil classification}

Based on morphological and physico-chemical characteristics, soils were classified into different soil-groups adopting the standard procedure (Soil Survey Staff, 1999).

The classification took in to account of presence and absence of diagnostic surface and subsurface horizons, temperature and moisture regimes and other specific characters (Table 4).

The Pedon 1 in the present study was grouped in Inceptisols soil order due to change in color and some accumulation of clay in sub-surface horizon indicating the presence of cambic B horizons. All the pedons belonged to Usteps suborder since they had Ustic soil moisture regime. The horizons were simple and no calcic or gypsic or duripan were observed, thus they fell in Haplustepts Great Group. All the pedons represented the central concepts of great group and hence classified as Typic Haplusteps at subgroup level. These results are in conformity with those of Patil and Prasad (2004).

The Pedon 2 were set out in Alfisols due the presence of argillic horizons (Bt i.e. accumulation of clays) with ustic soil moisture regime and thus belonged to Ustalfs suborder, since the horizons sampled had no calcic or gypsic or duripan observed and placed in Haplustalfs Great Group. Finally this pedon has been classified at subgroup level as Typic Haplustalfs being representing the central concept of Great Group. Gupta et al., (1999) 
and Pradeep and Verma (2005) have also reported the similar results with Haplusters.

The Pedon 3 was classed in Vertisolssoil order because of the presence of wide cracks, slicken sides and high clay content. Due to the presence of ustic soil moisture regime, it was placed in usterts suborder. No salic or gypsic or calcic or duripan were observed in subsurface horizons, hence, it belonged to Haplusters Great Group. Further it was classified as typic at subgroup level since it represented the central concept of Great Group. The results corroborate the findings of Gupta et al., (1999) and Singh et al., (2000).

\section{References}

Ahuja, L.R., Naney, J., Williams, W.R.D. and Ross, J.R. 1988. Vertical variability of soil properties in the small watershed. J. Hydrology 99: 307-318.

Bhaskar, B.P. and Sarkar, D. 2013. Capability and quality assessment of rice growing hydric soils in Majuli Island, Assam, India. Journal of Agriculture and Environment for International Development 107,13-32.

Brar, M.S. and Sekhon, G.C. 1987.Vertical distribution of potassium in five benchmark Soil series in North India. J. Indian Soc. Soil Sci. 35: 732-735.

FAO 1977. Guidelines for soil profile description 2nd edition. Soil Resource Development and Conservation Service, Land and Water Development Division, FAO, Rome :66.

Gupta, G. P., Tembhare, B. B. and Mishra, S. R. 1999. Characterization and classification of soils of granitic terrain in Jabalpur district of Madhya Pradesh. Agropedology, 9: 77-81.

Jewitt, T.N., Law, R.D. and Virgo, K.J. 1979. Outlook on agriculture as quoted by W.A. Blochurs morphology and genesis of Vertisols. In Vertisols and
Rice Soils of Tropics, 12th International Congress of Soil Science, Februry 8-16, 1982, New Delhi.

Kumar, T.V.; Reddy, M.S. and Krishna, V.G. (1996). Vertical distribution of micronutrients cations in some soil profiles in Northern Telungana of Andhra Pradesh. J. Indian Soc. SoilSci.44: 328-330.

Meena R.S. and Natarajan, A. 2014. Characterization and classification of lowland soils of Chikkarsinkere Hobli, Maddurtaluk, Mandya district of Karanataka. Agropedology 24 (01), 95-101.

Mishra Antaryami, 2005. Characterization, fertility status and taxonomic classification of some soils of west central table and agroclimatic zone of Odisha; Ph.D. Thesis, Dept. of Soil Science and Agricultural Chemistry, OUAT, Bhubaneswar.

Munsell Color Company 1954.Munsell Soil Color Charts. Munsell Color Co. Inc. Baltimore.

Pal, S. K. and Mukhopadhyay, A. K. 1992.Distridution of different forms of potassium in profiles of some Entisols. J. Indian Soc. Soil Sci. 40: 371-373.

Paramasivan, M. and Jawahar, D. 2014. Characterization, classification and crop suitability of some black cotton soils of southern Tamil Nadu. Agropedology 24 (8), 111-118.

Patil, R. B. and Prasad, Jagdish 2004. Characteristics and classification of some Sal (Shorearobusta) supporting soils in Dindori district of Madhya Pradesh. Journal of the Indian Society of Soil Science, 52: 119-124.

Pradeep Kumar and Verma, T.S. 2005. Characteristics and Classification of some rice growing soils of Palam Valley of Himachal Pradesh Agropedology, 15(2) : 80-85. 
Ram, R.L., Sharma, P.K., Jha, P., Das, S.N. and Ahmad, N. 2010. Characterization and classification of soils of Nagarjunasagar catchment in Shorapurtaluk of Gulbarga district, Karnataka state. Agropedology. 20: 112-123.

Rao, A.P.V.P., Naidu, M.V.S., Ramawatharam, N. and Rao, G.R. 2008. Characterization, classification and evaluation of soils on different landforms

in RamachandrapuramMandal of Chittoor district in Andhra Pradesh for sustainable land use planning. J. Indian Soc. Soil Sci. 56: 23-33.

Rao, A.P.V.P., Naidu, M.V.S., Ramawatharam, N. and Rao, G.R. 2008. Characterization, classification and evaluation of soils on different landforms in Ramachandrapuram Mandal of Chittoor district in Andhra Pradesh for sustainable land use planning. J. Indian Soc. Soil Sci. 56: 23-33.

Sangwan, B.S. and Singh, K. 1993. Vertical distribution of $\mathrm{Zn}, \mathrm{Mn}, \mathrm{Cu}$ and $\mathrm{Fe}$ in semiarid soils of Haryana and their relationships with soil properties. Journal of the Indian Society of SoilScience41, 463-467.
Sarkar, D., Baruah, U., Gangopadhyay, S. K., Sahoo, A. K. and Velayutham, M. 2002. Characteristics and classification of soils of Loktak command area of Manipur for sustainable land use planning. Journal of the Indian Society of Soil Science, 50: 196-204.

Singh I.S. and Agrawal, H.P.2005. Characterization, genesis and classification of rice soils of Eastern Region of Varanasi, uttar Pradesh.Agropedology, 15: 29-38.

Singh, M.V. 2000.Micro and secondary nutrient and pollutants research in India. A co-ordinated report for 19982000. AICRP micro and secondary nutrient and pollutants elements in soils and plants. Indian institute in soil science, Bhopal, pp 1-136.

Soil Survey Staff (1999) soil taxonomy- A basic system of Soil Classification for making and interpreting, $2^{\text {nd }}$ edition, Agriculture Handbook No. 436, United States Department SCS, USDA, Washington, D.C. USA.

Tamgadge, D. B., K. S. Gajbhiye and W. V. Bankar, 2002, Evaluation of soil suitability for paddy cultivation in Chattisgarh - A parametric approach. J. Indian Soc. Soil Sci., 50: 81- 88.

\section{How to cite this article:}

Deepika Devdas, L. K. Srivastava and Mishra, V. N. 2021. Characterization and Classification of Different Soil Type of Gariyaband District of Chhattisgarh. Int.J.Curr.Microbiol.App.Sci. 10(02): 1667-1677. doi: https://doi.org/10.20546/ijcmas.2021.1002.197 